\title{
EFFECT OF DIFFERENT CONSTANT TEMPERATURE AND PHOTOPERIODS ON SOME BIOLOGICAL ASPECTS OF Chrysoperla carnea (STEPHENS) (NEUROPTERA: CHRYSOPIDAE) REARED ON COWPEA APHID, Aphis craccivora KOCH
}

El-Saeady, A.A.; I.L. Ibrahim; S.A. Hammad and S.S.Abd EI Fattah Economic Entomology Dept., Faculty of Agriculture, Al- Azhar Univ.

\begin{abstract}
Two experiments were carried out to evaluate the effect of three constant temperatures $\left(20,25\right.$ and $\left.30^{\circ} \mathrm{C}\right)$ and the influence of three photoperiods $(14 / 10,12 / 12$ and $10 / 14 \mathrm{~h}$. L/D) on the larval, pupal duration period and predation capacity of Chrysoperla carnea reared on Aphis carccivora.

In the $1^{\text {st }}$ experiment the obtained results showed that increasing of temperature resulted in decreasing in both larval and pupal durations period and reducing in the total numbers of consumed preys ( $A$. carccivora).

Results obtained in the $2^{\text {nd }}$ experiment proved that the long larval duration was at long photoperiod $14 / 10 \mathrm{~h}$. L/D). To the contrary, the highest numberd of consumed prey by $C$. carneu was achieved under short day (10/14 h. L/D).
\end{abstract}

\section{INTRODUCTION}

Green lacewing, Chrysoperla carnea (Stephens) is one of the most beneficial and prolific predator, (Family Chrysopidae, Order Neuroptera), also known as aphid lion. It is found in different agricultural habitats with high relative frequency of occurrence. Larvae feed on several hurmful agricultural insect pests, however, it prey on thrips, aphids and eggs of Spodoptera littoralis, (Awadallah et al., 1975) while adults feed only on nectar, pollen and honey dew. Chrysopids show high resistance towards many widely used pesticides (Bigler, 1984). The predator efficiency as a biocontrol agent is affected by diet and prevailing weather factors such as temperature (Canard and Principi, 1984; Venzon and Carvalho, 1993) and is influenced by also, photoperiods. Therefore, the objective of the current investigation was to study the effect of constant temperatures, photoperiods and diet (aphid species as a prey) on some biological aspects of $C$. carnea individuals which known mass rearing, which can be utilized during field release of this chrysopid for the management of aphid population.

\section{MATERIALS AND METHODS}

Lacewings Chrysoperla carnea eggs were obtained from Biological Control Laboratory El-Arnaouty, S.A., Faculty of Agric. Cairo Univ., Egypt. Two experiments were carried out, in the first one, larvae were reared at three different constant temperatures 20,25 and $30^{\circ} \mathrm{C}$. while in the second experiment, larvae were reared at three levels of phoptoperiods (light/dark hours, $10 / 14,12 / 12$ and $14 / 10)$ under constant temperature $\left(25^{\circ} \mathrm{C}\right)$. Newly 
hatched larvae were used in the experiments. Duration of each larval instars, total larval period as well as the pupal period were recorded. Percentages of larval and pupal mortalities were also estimated. These experiments were carried out with the help of constant temperature rooms and photo boxes in the laboratory of El-Arnaouty, S.A., Faculty of Agric. Cairo Univ., Egypt.

To study the consumption capacity, newly hatched larvae of $C$. carnea were transferred with the help of soft and moist camel hair brush, singly, in 15 plastic jars $(20 \times 10 \mathrm{~cm})$ having 90 prey aphids, A. craccivora covered by muslin kept in position by rubber bands. Jars were kept under laboratory conditions of at constant temperatures $\left(20,25\right.$ and $\left.30^{\circ} \mathrm{C}\right)$ and under three phoptoperiods light/Dark hours $(10 / 14,12 / 12$ and $14 / 10)$ at $25^{\circ} \mathrm{C}$ separately as per requirement. The consumed number of aphids was counted daily and recorded and the prey food $A$. craccivora of each plastic jars was changed daily, so that there was always plenty of food available, until the predator completed their larval development. The consumption capacity for each larval instars of $C$. carnea was recorded under the constant temperatures $\left(20,25\right.$ and $\left.30^{\circ} \mathrm{C}\right)$ and under the three phoptoperiods.

Each experiment was adequately replicated and data were evaluated statistically to determine the significant difference by using Duncan (1955) and by using proc. Anova in SAS (SAS Institute 1996).

\section{RESULTS AND DISCUSSION}

\section{Effects of temperatures on larval and pupal duration periods of $C$. carnea:}

As shown in Table (1) the mean total durations of the $1^{\text {st }}$ larval instar of C. carnea at constant temperatures of 20,25 and $30^{\circ} \mathrm{C}$ were $4.09 \pm 0.3$, $2.38 \pm 0.52$ and $2.64 \pm 0.50$ days; while they were $3.36 \pm 0.81,2.88 \pm 0.35$ and $2.0 \pm 0.0$ days; in case of $2^{\text {nd }}$ larval instar respectively. However, in $3^{\text {rd }}$ larval instar durations were $7.36 \pm 0.67,5.88 \pm 0.64$ and $5.27 \pm 0.47$ days the previously mentioned temperatures, respectively. The averages of the total duration of the larval stage at 20,25 and $30^{\circ} \mathrm{C}$ were $14.81 \pm 1.78,11.14 \pm 1.51$ and $9.91 \pm 0.97$ days.

Table (1): Duration period (days) of larval and pupal stages of Crysoperla carnea fed on Aphis craccivora at different constant temperatures.

\begin{tabular}{|c|c|c|c|c|c|c|}
\hline \multirow{2}{*}{$\begin{array}{l}\text { Constant } \\
\text { Temp. }\end{array}$} & \multicolumn{4}{|c|}{ Larval stage } & \multirow[b]{2}{*}{ Pupal stage } & \multirow[b]{2}{*}{ Total } \\
\hline & $1^{\text {st }}$ instar & $2^{\text {nd }}$ instar & $3^{\text {rd }}$ instar & $\begin{array}{c}\text { Larval } \\
\text { duration }\end{array}$ & & \\
\hline 20 & $4.09 \pm 0.30 a$ & $3.36 \pm 0.81 a$ & $7.36 \pm 0.67 a$ & $14.81 \pm 1.78 a$ & $10.73 \pm 3.74 a$ & $25.54 \pm 7.30 a$ \\
\hline 25 & $2.38 \pm 0.52 b$ & $2.88 \pm 0.35 b$ & $5.88 \pm 0.64 b$ & $11.14 \pm 1.51 b$ & $8.81 \pm 3.23 a$ & $19.95 \pm 4.74 b$ \\
\hline 30 & $2.64 \pm 0.50 \mathrm{~b}$ & $2.0 \pm 0.0 \mathrm{c}$ & $5.27 \pm 0.47 c$ & $9.91 \pm 0.97 c$ & $4.82 \pm 3.10 \mathrm{~b}$ & $14.73 \pm 4.07 \mathrm{c}$ \\
\hline $\mathrm{LSD}_{0.05}$ & 0.367 & 0.433 & 0.493 & 2.815 & 2.796 & 2.820 \\
\hline
\end{tabular}

Means followed by the same latter between rows are not significantly different (Duncan, 1955). 
For the pupal stage, durations were at temperatures of 20, 25 and $30^{\circ} \mathrm{C}$ respectively, $10.73 \pm 3.74,8.81 \pm 3.23$ and $4.82 \pm 3.10$ days when the previous larvae were fed on $A$. craccivora (Table 1).

Statistical analysis of obtained data and revealed that, the duration of larval instars decreased significantly with the increase in temperatures. The duration of larval stage varied from $14.81 \pm 1.78$ days at $20^{\circ} \mathrm{C}$ to $9.91 \pm 0.97$ days at $30^{\circ} \mathrm{C}$. There was a considerable reduction in the total development period of the larvae with the increase in temperature.

The duration of pupal stage decreased as temperature increased and lasted $10.73 \pm 3.74,8.81 \pm 3.23$ and $4.82 \pm 3.10$ days at 20,25 and $30^{\circ} \mathrm{C}$ respectively. In general increasing in temperature resulted in decreasing in the duration of both larval and pupal stages. The results generally are in agreement with the finding of Patro and Behera (2002), Jagadish et al., (2004), Pooja Khulbe et al., (2005) Lohar et al., (2005), Sirimachan et al., (2005) and Kuldeep Sharma et al., (2008).

Effect of temperature on feeding capacity of $C$. carnea larvae:

Data in Table (2) showed that the total consumptions by each of three larval instars of $C$. carnea fed on $A$. craccivora at three different constant temperatures; 20,25 and $30 \mathrm{C}$. The $1^{\text {st }}$ instar larva consumed $33.55 \pm 2.25,12.88 \pm 5.14$ and $18.27 \pm 5.33$ aphids individuals; the $2^{\text {nd }}$ preyed on $78.09 \pm 29.94,40.50 \pm 16.82$ and $25.0 .9 \pm 2.47$ victims, and the $3^{\text {rd }}$ larval instar consumed $472.27 \pm 77.13,291.63 \pm 26.21$ and $212.55 \pm 45.51$ aphids at 20,25 and $30^{\circ} \mathrm{C}$ respectively.

Throughout the total larval stage, the mean of total count of consumed aphids by $C$. carnea larva at different constant temperatures at 20 , 25 and $30^{\circ} \mathrm{C}$ was $583.91 \pm 101.07,345.0 \pm 30.80$ and $256.27 \pm 52.08$ nymphs when each larval instar was fed on $A$. craccivora at different constant temperatures at 20,25 and $30^{\circ} \mathrm{C}$ respectively.

Table (2): Mean number of aphids individuals ( $A$. craccivora) consumed by the three larval instars of $C$. carnea at different constant temperatures.

\begin{tabular}{|c|c|c|c|c|}
\hline \multirow{2}{*}{$\begin{array}{l}\text { Constant } \\
\text { Temp. }\left({ }^{\circ} \mathrm{C}\right)\end{array}$} & \multicolumn{3}{|c|}{ Larval instars } & \multirow[b]{2}{*}{ Total } \\
\hline & $1^{\text {st }}$ instar & $2^{\text {nd }}$ instar & $3^{\text {rd }}$ instar & \\
\hline 20 & $33.55 \pm 2.25 a$ & $78.09 \pm 29.94 a$ & $472.27 \pm 77.13 a$ & $588.91 \pm 101.07 a$ \\
\hline 25 & $12.88 \pm 5.14 \mathrm{c}$ & $40.50 \pm 16.82 b$ & $291.63 \pm 26.21 b$ & $345.0 \pm 30.80 \mathrm{~b}$ \\
\hline 30 & $18.27 \pm 5.33 b$ & $25.09 \pm 2.47 \mathrm{~b}$ & $212.55 \pm 45.51 \mathrm{c}$ & $256.27 \pm 52.08 c$ \\
\hline $\mathrm{LSD}_{0.05}$ & 3.625 & 16.679 & 46.61 & 58.719 \\
\hline
\end{tabular}

Means followed by the same latter between rows are not significantly different (Duncan, 1955).

From data in Table (2) could be stated that, the total consumption of aphids by the larvae of $C$. carnea decreased with increase of the temperature. It is cleared that the $3^{\text {rd }}$ instar larvae of $C$. carnea fed on the highest numbers of aphids compared to other instars. At $20^{\circ} \mathrm{C}$ the $1^{\text {st }}$ instar larva fed on $33.55 \pm 2.25$ aphids the $2^{\text {nd }}$ instar fed on $78.09 \pm 29.94$ aphids and the $3^{\text {rd }}$ larval instar consumed $472.27 \pm 77.13$ aphids. While the lowest mean number of consumed aphids were recorded at $30^{\circ} \mathrm{C}$, this difference is mathematically highly significant. It is obvious that predaceous capacity 
increases from the first to last instars at different temperatures (Table 2). Similar results were reported by Yuksel and Gocmen (1992), Fonseca et al., (2001), Patro and Behera (2002), Sirimachan et al., (2005) Renu-Yadav and Pathak (2010).

Effects of photoperiods on larval and pupal duration periods of $C$. carnea:

As shown in Table (3) the mean durations of the $1^{\text {st }}$ larval instar under three photoperiods (light/Dark hours, 10/14, 12/12 and 14/10) were $1.38 \pm 0.52,1.80 \pm 0.63$ and $2.79 \pm 0.43$; they were $2.0 \pm 0.0,2.50 \pm 0.71$ and $2.64 \pm 1.01$; in the $2^{\text {nd }}$ instar while they were $6.38 \pm 1.92,6.25 \pm 2.01$ and $4.86 \pm 0.66$ days in case of the $3^{\text {rd }}$ one respectively. The averages of the total duration of the larval stage under the three photoperiods were $9.76 \pm 2.44$, $9.83 \pm 3.35$ and $10.29 \pm 2.10$ days, respectively.

Different photoperiods also affected the pupal duration of $C$. carnea as shown in Table (3). Pupal durations were $9.69 \pm 0.26,7.52 \pm 2.63$ and $8.75 \pm 2.56$ days under the three photoperiods, respectively.

Table (3): Duration (days) of larval and pupal stages of Crysoperla carnea feeding on Aphis craccivora at three different photoperiods.

\begin{tabular}{|c|c|c|c|c|c|c|}
\hline \multirow{2}{*}{$\begin{array}{c}\text { Photo- } \\
\text { periods } \\
(\mathbf{L} / \mathrm{D})\end{array}$} & $\mathbf{1}^{\text {stinstar }}$ & $\mathbf{2}^{\text {nd }}$ instar & $\mathbf{3}^{\text {rd }}$ instar & $\begin{array}{c}\text { Larval } \\
\text { duration }\end{array}$ & $\begin{array}{c}\text { Pupal } \\
\text { duration }\end{array}$ & \multirow{2}{*}{ Total } \\
\hline $10 / 14$ & $1.38 \pm 0.52 \mathrm{c}$ & $2.00 \pm 0.0 \mathrm{~b}$ & $6.38 \pm 1.92 \mathrm{a}$ & $9.76 \pm 2.44 \mathrm{c}$ & $9.69 \pm 0.26 \mathrm{a}$ & $19.44 \pm 1.66 \mathrm{~b}$ \\
\hline $12 / 12$ & $1.80 \pm 0.63 \mathrm{~b}$ & $2.50 \pm 0.71 \mathrm{c}$ & $6.25 \pm 2.01 \mathrm{a}$ & $9.83 \pm 3.35 \mathrm{~b}$ & $7.52 \pm 2.63 \mathrm{~b}$ & $18.07 \pm 0.93 \mathrm{c}$ \\
\hline $14 / 10$ & $2.79 \pm 0.43 \mathrm{a}$ & $2.64 \pm 1.01 \mathrm{a}$ & $4.86 \pm 6.66 \mathrm{~b}$ & $10.29 \pm 2.10 \mathrm{a}$ & $8.75 \pm 5.56 \mathrm{ab}$ & $19.04 \pm 2.89 \mathrm{a}$ \\
\hline $\mathrm{LSD}_{0.05}$ & 0.343 & 0.515 & 1.015 & - & 1.497 & - \\
\hline
\end{tabular}

Means followed by the same latter between rows are not significantly different (Duncan, 1955).

Statistical analysis showed that photoperiods had significant effect on the durations of the first, second and third instars. Consequently, the total larval duration was significantly affected. The shortest larval duration of $9.76 \pm 2.44$ days recorded for larvae reared under short day (10/14), while the longest durations (10.29 \pm 2.01 days) occurred under long (14/10 h. L/D). However, photoperiod seems to have no profound effect on the pupal duration since no significant difference was detected between means of larvae pupal duration under different experimental light regimes.

Same type of result was also reported by El-Khawas (1989), Fonseca et al., (2001) and Figueira et al., (2002).

Effect of photoperiods on feeding capacity of $\boldsymbol{C}$. carnea larvae:

Data in Table (4) showed that the total consumptions by each of three instars of C.carnea on $A$. craccivora at three photoperiods light/Dark hours $(10 / 14,12 / 12$ and $14 / 10)$. The $1^{\text {st }}$ instar larva fed on $8.75 \pm 4.62$, $11.80 \pm 4.69$ and $16.5 \pm 4.03$ aphids; the $2^{\text {nd }}$ on $23.50 \pm 3.07,29.70 \pm 15.90$ and the $3^{\text {rd }}$ larval instar on $281.88 \pm 165.84,266.14 \pm 129.28$ and $226.57 \pm 51.57$ aphids at the three photoperiods light/Dark hours (10/14, 12/12 and 14/10) respectively. 
Throughout the total larval stage, the mean of total consumed preys by $C$. carnea larvae at the three photoperiods light/Dark hours $(10 / 14,12 / 12$ and $14 / 10)$ were $314.13 \pm 124.53, \quad 307.64 \pm 129.19$ and $275.43 \pm 72.05$ individuals, respectively.

Table (4): Mean number of aphids ( $A$. craccivora) consumed by the three larval instars of $C$. carnea at different three photoperiods.

\begin{tabular}{|c|c|c|c|c|}
\hline \multirow{2}{*}{$\begin{array}{c}\text { Photoperiods } \\
(\mathbf{L} / \mathbf{D})\end{array}$} & $\mathbf{1}^{\mathbf{s t}}$ instar & $\mathbf{2}^{\text {nd }}$ instar & $\mathbf{3}^{\text {rd }}$ instar & Total \\
\hline $10 / 14$ & $8.75 \pm 4.62 \mathrm{c}$ & $23.50 \pm 3.07$ & $281.88 \pm 165.84$ & $314.13 \pm 124.53$ \\
\hline $12 / 12$ & $11.80 \pm 4.69 \mathrm{~b}$ & $29.70 \pm 15.90$ & $266.14 \pm 129.28$ & $307.64 \pm 129.19$ \\
\hline $14 / 10$ & $16.5 \pm 4.03 \mathrm{a}$ & $32.36 \pm 28.30$ & $226.57 \pm 51.57$ & $275.43 \pm 72.05$ \\
\hline $\mathrm{LSD}_{0.05}$ & 2.893 & - & - & - \\
\hline
\end{tabular}

Means followed by the same latter between rows are not significantly different (Duncan, 1955).

Through the present data, it appears that the number of aphids consumed by different larval instars of $C$. carnea progressively increases throughout the larval period and the largest amount of consumed aphids was persistently reported for the third larval instar under different photoperiod conditions. The results are in agreement with those previously reported by ElKhawas (1989), Fonseca et al., (2001), Sirimachan et al., (2005) and Gao Feng et al., (2007).

\section{REFERENCES}

Awadallah, K.T.; Abouzeid, N.A. and Tawfik, M.F.S. (1975): Devlopment and fecundity of Chrysopa carnea Stephens. Bull. Soc. Ent. Egypt., 59: 323-329.

Bigler, F. (1984): Biological control by chrysopids: Integration with pesticides. In Canard, M., Semeria, Y and New, R. T. Eds., Biology of Chrysopids. Junk, Boston. pp. 233-245.

Canard, M. and Principi, M.M. (1984): Development of Chrysopidae, In: M. Canard., Y. Semeria and T.R. New (Eds). Biology of Chrysopidae. The Hague, W. Junk Publisher. p. 294.

Duncan, D.B. (1955): Multiple range and multiple $F$ test. Biometrics, 11: 1-32.

El-Khawas, K.A.M. (1989): The role of biological agents a regulating factor for populations of some insects transmiting diseases to vegetable crops under protected agricultural system. M. Sc. Thesis. Fac. Agric., AlAzhar University.

Figueira, L.K.; Carvalho, C.F. and Souza, B. (2002): Influence of temperature on some biological aspects of Chrysoperla externa (Hagen, 1861) (Neuroptera: Chrysopidae) fed on Alabama argillacea (Hubner, 1818) (Lepidoptera: Noctuidae) eggs: Cienciae Agrotecnologia, 26: 14391450. 
Fonseca, A.R.; Carvalho, C.F. and Souza, B. (2001): Predatory capacity and biological aspects of the immature stages of Chrysoperla externa (Hagen, 1861) (Neuroptera: Chrysopidae) fed on Schizaphis graminum (Rondani, 1852) (Hemiptera: Aphididae) under different temperatures. Cienciae Agrotecnologia, 25(2): 251-263.

Gao Feng; Liu XiangHui and Ge Feng (2007): Energy budgets of the Chinese green lacewing (Neuroptera: Chrysopidae) and its potential for biological control of the cotton aphid (Homoptera: Aphididae). Insect Science, 14(6): 497-502.

Jagadish, K.S.; Jayaramaiah, M. and Shivayogeshwara, B. (2004): Effect of temperature and relative humidity regimes on the life cycle of the green lacewing Chrysoperla carnea (Steph.) (Neuroptera: Chrysopidae). Environment and Ecology, 22(4): 755-758.

Kuldeep Sharma; Khan, M.A. and Suneel Kumar (2008): Studies on biological parameters of Chrysoperla carnea Stephens (Neuroptera: Chrysopidae) at different temperature regimes. Pantnagar Journal of Research, 6(1): 20-22.

Lohar, M. K.; Huma Memon and Aslam Bukero (2005): Biology and feeding potential of green lacewing, Chrysoperla carnea Stephens (Neuroptera: Chrysopidae) on mustard aphid. Proceedings of Pakistan Congress of Zoology, 25: 57-63.

Patro, B. and Behera, M.K. (2002): Biology and feeding potential of Chrysoperla carnea (Stephens) (Neuroptera: Chrysopidae) on the bean aphid, Aphis craccivora Koch. Journal of Biological Control, 16(1): 7779.

Pooja Khulbe; Maurya, R.P. and Khan, M.A. (2005): Biology of Chrysoperla carnea (Stephens) on different host insects. Annals of Plant Protection Sciences, 13(2) 351-354.

Renu-Yadav and P.H. Pathak (2010): Effect of temperature on the consumption capacity of Chrysoperla carnea (Stephens) (neuroptera: chrysopidae) reared on four aphid species. The Biosean, 5(2): 271 274.

SAS (1996): SAS User's Guide statistics, SAS Institute, Cary, N.C.

Sirimachan, N.; Kern-asa, O.; Amornsak, W. and Suasa-ard, W. (2005): Biological study and efficiency of the green lacewing, Mallada basalis (Walker) (Neuroptera: Chrysopidae) as biological control agent of Aphis craccivora Koch (Homoptera: Aphididae). Proceedings of 43rd Kasetsart University Annual Conference, Thailand, 1-4 February, 2005. Subject: Plants, 124-131.

Venzon, M. and Carvalho, C.F. (1993): Desenvolvimento larval, Prepupal pupal de Ceraeochryso cubana (Hagen) (Neuroptera: Chrysopidae) diferentes dietas temperatures. Anais da Sociedade Entomologica do Brasil. Londrina., 22: 477-483.

Yuksel, S. and Gocmen, H. (1992): The effectiveness of Chrysoperla carnea (Stephens) (Neuroptera, Chrysopidae) as a predator on cotton aphid Aphis gossypii Glov. (Homoptera, Aphididae). Proceedings of the Second Turkish National Congress of Entomology, 209-216. 
تأثير كل من درجـات الحرارة والاضساءة الثابتتين على بعض النواحى البيولوجية

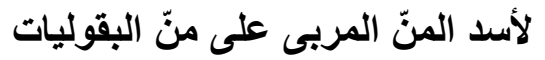

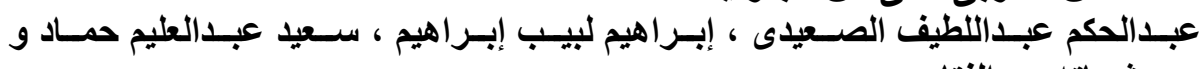
سيا شحاته عبدالفتاح قسم وقاية النبات ـ كلية الزراعة - جامعة الازهر-القاهرة.

تم إجر اء تجربتين منفصلتين لتقاير تأثير ثلاث درجات حر ارة ثابته ومختلفة (20، 25،

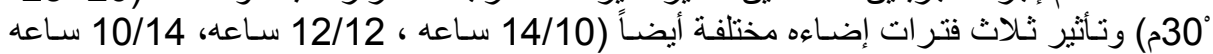

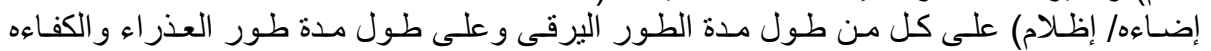
الافتر اسية للمفترس الحشرى أسند المنّ.

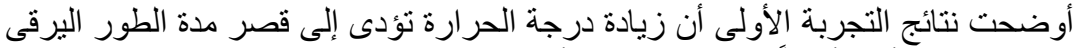

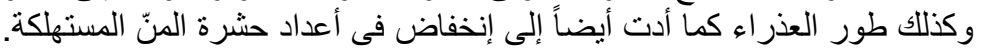

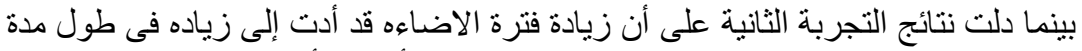

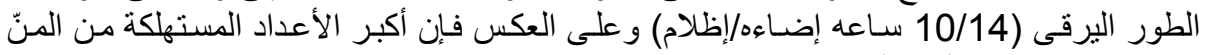
كانت تحت ظروف اليوم القصير (14/10 ساعة إضاءه/إظلام).

كلية الزراعة - جامعة المنصورة كلية الزراعة - جامعة الازهة - القعاهرة

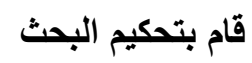

أ. أد / عبد البديم البحث عبد الحمبد غاتم

أ.د / أد / عحمد عبد البفعار محمود الغمبد 